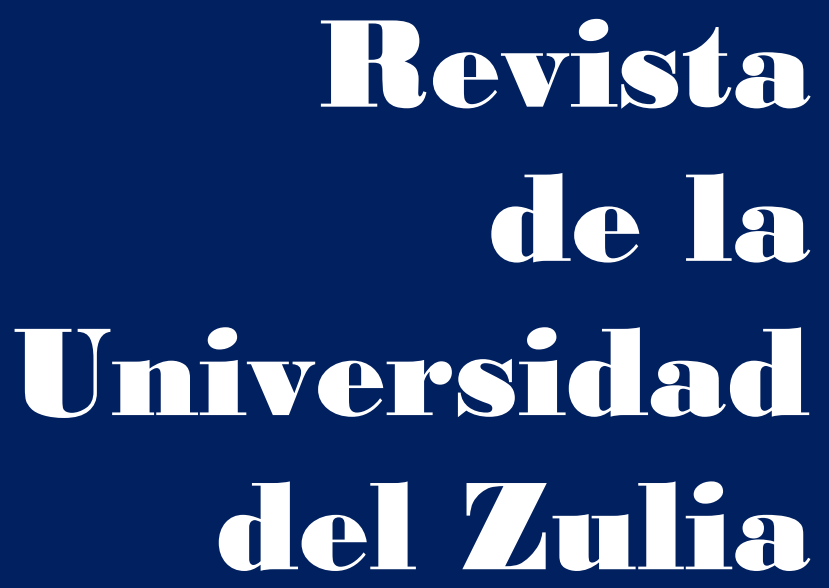

Fundada en 1947

por el Dr. Jesús Enrique Lossada

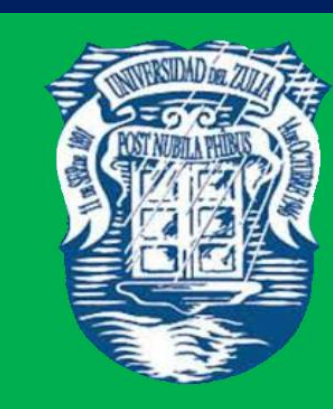

Ciencias del

Agrad,

Ingemiería

y Tecinología

\section{Aกัต 13 No $\mathbf{3 6}$} Enero - Abril 2022

Tercera Épaca

Maracailbo-Venezuela 


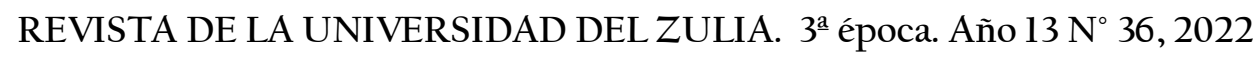

Svetlana E. Germanova et al. /// Environmental security problems in mining areas, 323-338 DOI: http://dx.doi.org/10.46925//rdluz.36.21

\title{
Environmental security issues in mining areas
}

\author{
Svetlana E. Germanova * \\ Vadim G. Pliushchikov ** \\ Tatiana V. Magdeeva *** \\ Tatiana A. Ryzhova **** \\ Nikolay V. Petukhov *****
}

\begin{abstract}
In today's economy, it is necessary to explore the environmental impact of mining. Coal mining greatly affects all environmental parameters of the environment: home, production, hydrodynamics. The environmental situation in the area of the mining company can be changed if environmental contamination is monitored and environmental protection plans and measures are developed. The purpose of this work is the analysis of systems and models of these processes in the ecosystem. The main systemic hypothesis of the research is that the variety of criteria and methods of risk assessment is a necessary condition of order in the system. The main results of the work are the following: 1) a systematic analysis of the problems of environmental security, geodynamics of the mining areas, aspects of the balance of the sustainable process and the cause of the increase in danger was carried out; 2) Proposed approaches (models) for the assessment of evolutionary ecological potential and health risks, as well as adaptive situational modeling of the ecosystem. It is important to note, the study results do not suggest complex environmental monitoring studies.
\end{abstract}

KEYWORDS: Environment; Environmental degradation; Coal mining; Environmental impact assessment.

*Senior Lecturer of the Department of Technosphere Security of the Agrarian and Technological Institute, Peoples' Friendship University of Russia, ORCID: https://orcid.org/00000-0003-2601-6740. E-mail: germanova-se@rudn.ru

**Doctor of Agricultural science, Professor, Director of the Department of Technosphere Security of the Agrarian and Technological Institute, Peoples' Friendship University of Russia. ORCID: https://orcid.org/0000-0003-2057-4602. E-mail: pliushchikov-vg@rudn.ru

***Senior Lecturer of the Department of Technosphere Security of the Agrarian and Technological Institute, Peoples' Friendship University of Russia. ORCID: https://orcid.org/0000-0002-5584-5321. E-mail: dremovatv@rudn.ru

****Candidate of physical and mathematical sciences, Senior Lecturer of the Institute of Physical Research and Technology of the Faculty of Physics and Mathematics and Natural Sciences, Peoples' Friendship University of Russia. ORCID: https://orcid.org/0000-0003-1837-8899. E-mail: ryzhova-ta@rudn.ru

*****Candidate of Agriculture Science, Associate Professor of the Department of Technosphere Security of the Agrarian and Technological Institute, Peoples' Friendship University of Russia. ORCID: https://orcid.org/0000-0003-1521-2797. E-mail: petukhov-nv@rudn.ru

This paper has been supported by the RUDN University Strategic Academic Leadership Program.

Recibido: 04/10/2021

Aceptado: 01/12/2021 


\section{Problemas de seguridad ambiental en áreas mineras}

\section{RESUMEN}

En la economía actual, es necesario explorar el impacto ambiental de la minería. La minería del carbón afecta en gran medida todos los parámetros ambientales del medio ambiente: hogar, producción, hidrodinámica. La situación ambiental en el área de la empresa minera se puede cambiar si se monitorea la contaminación ambiental y se desarrollan planes y medidas de protección ambiental. El propósito de este trabajo es el análisis de sistemas y modelos de estos procesos en el ecosistema. La principal hipótesis sistémica de la investigación es que la variedad de criterios y métodos de evaluación del riesgo es una condición necesaria del orden en el sistema. Los principales resultados del trabajo son los siguientes: 1) se realizó un análisis sistemático de los problemas de seguridad ambiental, geodinámica de las áreas mineras, aspectos del equilibrio del proceso sostenible y la causa del aumento del peligro; 2) enfoques propuestos (modelos) para la evaluación del potencial ecológico evolutivo y los riesgos para la salud, así como el modelado situacional adaptativo del ecosistema. Es importante destacar que los resultados del estudio no sugieren estudios complejos de monitoreo ambiental.

PALABRAS CLAVE: medio ambiente; deterioro ambiental; minería de carbón; evaluación del impacto ambiental.

\section{Inroduction}

Environmental security problems (hereinafter referred to simply as "safety") in mining areas are related both to changes in the biosphere and the noosphere. Everything should be considered taking into account the biosphere and noosphere, forest losses, the disposal of large pastures and arable land. Safety is growing with the growth of plowing of land in river floodplains, indiscriminate construction of dams, forest fires, deforestation and mining, for example, the production of limestones, dolomites, etc.

Mining, coal burning seriously affects the biosphere, the whole nature. The coal industry and coal-fired thermal power plants cause the greatest environmental damage.

With the growth of construction and engineering work, negative processes of a geodynamic nature attract the attention of scientists, for example, note Brussels, Pepper and Gerba (2019:219), Sklarew (2018), Kolesnikova and Kovalchuk (2021). During rock development, dust, gases are released into the atmosphere during drilling and blasting operations, as well as during transportation, pollutants are discharged into wastewater. 
REVISTA DE LA UNIVERSIDAD DEL ZULIA. $3^{a}$ época. Año $13 \mathrm{~N}^{\circ}$ 36, 2022

Svetlana E. Germanova et al. /// Environmental security problems in mining areas, 323-338

DOI: http://dx.doi.org/10.46925//rdluz.36.21

Geodynamics of mining areas is formed by karst depressions, tectonic disorders and weakening of the earth's crust. In conditions of non-equilibrium physical and chemical processes, mining areas themselves become unstable, the cause of negative geoprocesses of increased danger.

Contamination of the mining area is dangerous not only for the biosphere, but also for agricultural products falling on our table. Various impurities (pollution factors) come both from natural-anthropogenic sources and from human life and production. These are dust (desertification), salt (salinization), smoke-gas (forest and steppe fires), etc.

Anthropogenic pollutants from numerous sources of emissions pose a threat to health and human life. The list of pollutants includes more than 4,000 impurities, specific, regional and regional, near the point.

The safety of the area is based on the prediction and elimination of hazardous and risk situations of various types to identify the unacceptable level of impact of environmental pollution factors (Shafiquzzaman and Alharbi, 2020; Liang and Xiao, 2020). In Russia, the share of coal production was more than 75\% (Tarazanov and Gubanov, 2020) and there is a stable balance in the mining region, which is a strategic advantage of economic and environmental safety (Kulikova and Balovtsev, 2020).

In Russia, coal waste reserves are estimated at 80-120 billion tons (an annual increase of about 7 billion tons), and only 5-10\% of them are processed (State report, 2019:389). In the world - the picture is similar. South, South-East and West Asia are the most polluted parts of the world, especially cities (the countries of this Asia are located in the 30 most polluted cities in the world). For example, according to (Statistical Review, 2021:47), you can construct the histogram shown in Figure 1.

The use of fuel coal in thermal power plants seriously affects the environment, with all its 278 different impacts, and this is the monthly cause (Kobylkin and Musina, 2019) of more than 7 million premature deaths in the world: from lung cancer (29\%), acute respiratory infection (17\%), stroke (24\%), ischemia (25\%), chronic lung disease (43\%).

The purpose of this work is system analysis-synthesis and simulation-forecasting of key processes affecting environmental safety and pollution risks in mining. A procedure for assessing its evolutionary potential, "ecological debt", mathematical models and expert heuristic procedures are also proposed. The application of Big Data, Smart Mining, AI, 
REVISTA DE LA UNIVERSIDAD DEL ZULIA. $3^{a}$ época. Año $13 \mathrm{~N}^{\circ}$ 36, 2022

Svetlana E. Germanova et al. /// Environmental security problems in mining areas, 323-338 DOI: http://dx.doi.org/10.46925//rdluz.36.21

situational modeling and other intelligent technologies in decision making is emphasized, for example, remote control, production dispatching, compensation of "environmental debt" (damage).

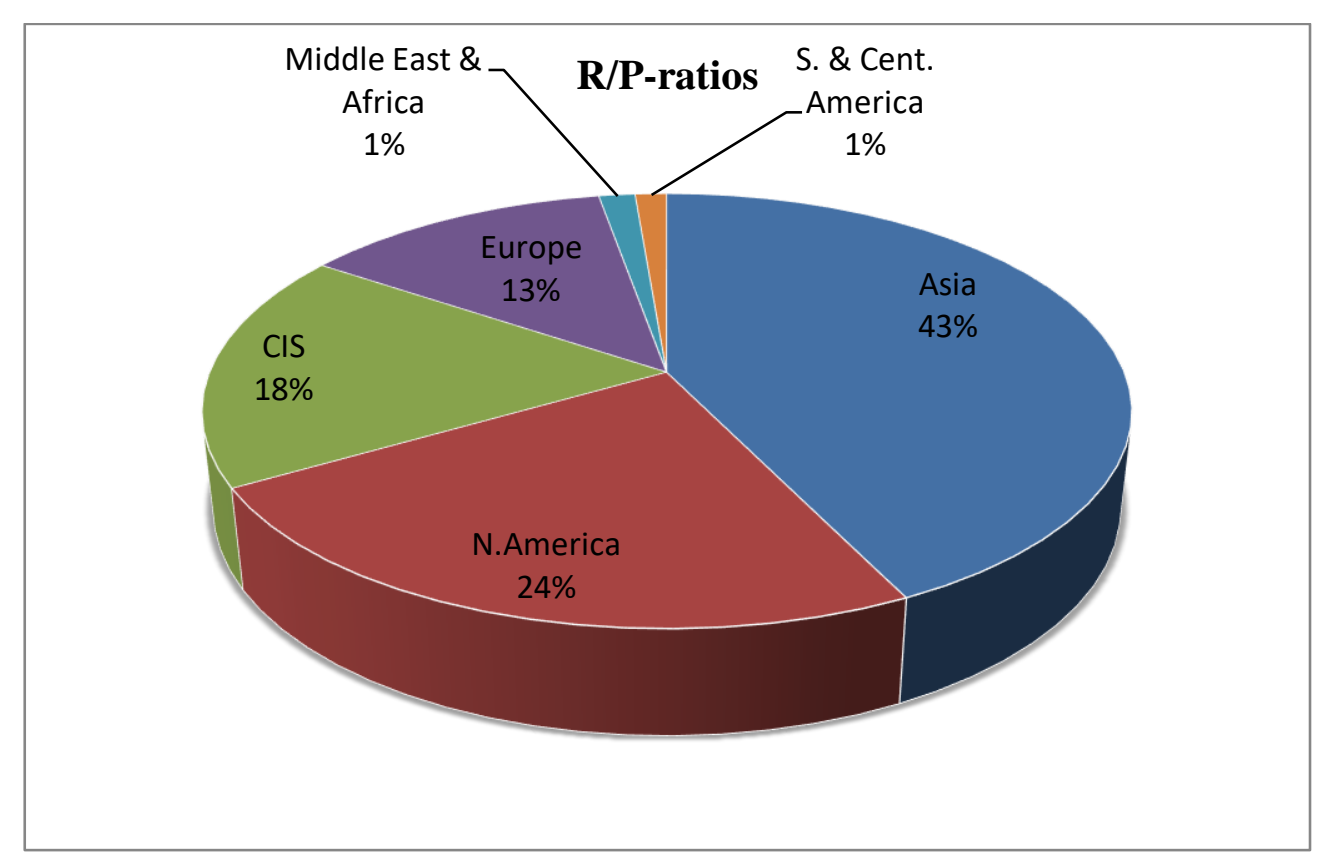

Fig.l. Distribution of proved reserved in 2020 (R/P - Reserves-to-Production)

1. Materials and methods

Structural factors affect tectonics, terrain, geological structure, and rock composition. Water stiffness increases, mineralization changes, rock vulnerability decreases, safety decreases. For example, karst features and hazards appear in the sulphate rocks of the Western Urals (Gayev and Kilin, 2018). Mountains reduce negative geodynamic processes. Scientists study processes using remote methods: topographic, hydrogeological and geophysical observations.

Hydrogeochemical methods of forecasting safety in hydrodynamic areas allow building maps of safety, tectonic movements, and increased stresses (depression) of the earth's surface. It became possible to monitor the erosion-tectonic and stress dynamics and introduce effective safety measures.

The rock array is a complex hierarchical structure, characterized by variability in stresses and properties. In order for geology and hydrogeology data arrays to become active 
REVISTA DE LA UNIVERSIDAD DEL ZULIA. $3^{a}$ época. Año $13 \mathrm{~N}^{\circ}$ 36, 2022

Svetlana E. Germanova et al. /// Environmental security problems in mining areas, 323-338 DOI: http://dx.doi.org/10.46925//rdluz.36.21

and be used for technical decisions, Big Data will be required with survey data, starting with the operation of the deposit and completing the process of computer modeling of the state of stresses. Such modeling allows taking into account the processes of mountain pressure, stress, critical state of rocks. This allows you to prevent mountain strikes, follow the rules and rules of development.

We use general (system) methods and private methods (experimental dependencies, models, etc.).

2. Systems approach, trends and digital transformation in mining security

The development of mining projects is carried out through the opening of new horizons, development, the use of new technologies, research. The development of production is also a complication of mining. The natural trend is to increase the efficiency of enterprises and mines.

There is a systemic problem - there is no single technological infrastructure, environment of settlements and projects, and the one that is - morally, technologically obsolete quickly, and the consequences of risks, dangers, poor security policies are increasing.

The reasons for the risks are as follows:

1) qualitative (quantitative) development of forms and structures of subsoil use and development of subsoil;

2) development of deep, therefore complex and inaccessible deposits;

3) geodynamic (seismic) activity;

4) intensive technologies with uncertain parameters of mining and excavation of structures, stress relaxation, large volumes of rocks;

5) synergistic processes and stable equilibrium states, increasing seismic activity.

Geodynamics and mechanics of mining processes complicate these causes, deterrent factors. Their systemic analysis/synthesis aimed at improving technology and safety and reducing environmental response time is needed. Systematization, regulation, intellectualization and modeling will allow you to move to a new, systemic (high-quality) level. 
REVISTA DE LA UNIVERSIDAD DEL ZULIA. $3^{a}$ época. Año $13 \mathrm{~N}^{\circ}$ 36, 2022

Svetlana E. Germanova et al. /// Environmental security problems in mining areas, 323-338 DOI: http://dx.doi.org/10.46925//rdluz.36.21

Optimizing or, at a minimum, rationalizing the use of coal deposits can help preserve natural resources from pollution and depletion, and people from social, economic, environmental and even production problems. Many companies reduce emissions to the atmosphere from the coal industry (Skopintseva, Balovtsev, 2021), use biotechnology and renewable or low-waste raw materials. Moving and deformations of the earth's surface at coal mining enterprises are being studied (Batugin, 2020).

Improving the environmental situation in the surrounding mining area is a systemic problem that is being addressed at the state level. But the analysis we have done makes it possible to note the priority problems on which the systemic solution of the problem in the regions depends, namely:

1) create joint environmental programs of enterprises, private business and public partnership;

2) ensure the freedom of investors, turn it into an advantage of free cooperation in conditions of ecological "non-freedom";

3) include the creation of a comfortable environment focused on quality of life, growth drivers and optimal parameters;

4) take into account the characteristics of export-import;

5) implement relevant forms of cooperation with stakeholders;

6) forecast prospects of trade liberalization (reduction of tariffs, duties);

7) provide logistics flows and build transit capacity;

8) develop activities and expand niches in markets, including the national market;

9) ensure safety in all its important aspects;

10) assess consumer interests and corporate risks of greening;

11) record, classify and compare geological and production data, etc.

In forecasting pollution in mining areas, the following are important:

1) organized and verifiable monitoring;

2) carefully prepared mathematical (numerical) modeling;

3) presence of representative methods, models (systems), especially, not requiring numerous and expensive, complex verification procedures.

From the point of view of the systemic approach to the problem, it should be taken into account that depressive funnels arise in the mountain range, leading to deformation 
REVISTA DE LA UNIVERSIDAD DEL ZULIA. $3^{a}$ época. Año $13 \mathrm{~N}^{\circ}$ 36, 2022

Svetlana E. Germanova et al. /// Environmental security problems in mining areas, 323-338 DOI: http://dx.doi.org/10.46925//rdluz.36.21

processes, increased seismic hazard, the formation of stored waste ("tailings", dumps). All this is a step towards irreversible bifurcations of environmental processes, the onset of global environmental changes and crises.

\section{Ecological potential of a sustainable mining area}

Industrial mining regions, coal mining areas need technological progress. It helps to combat the decline in environmental potential and disruption of equilibrium processes in the environment. Especially, on processes that lead to pollution, the strengthening of factors that dominate such processes (Kaledina, Kobylkin, 2016).

Mining, mining and mining in regions with ore reserves should be regulated by monitoring the potential for sustainable development, regulating the so-called "environmental debt". Environmental damage is limited to the relevant objective function, the area is charged with natural restoration work or compensation for damage with fines, depending on the intensity of pollution.

The maximum damage is determined according to regional policy, law and environmental and economic standards. In the assessment of environmental debt, the primary is not even the magnitude, but the dynamic increase in damage from economic activities.

The state of stability of the area is based on the actualization of connections with the environment, with the environment. Self-organization of production structures, evolutionary potential and prediction of the evolutionary capabilities of the system are a prerequisite for a systemic approach. As well as the need for situational modeling of interactions with the environment.

Effective criteria, indices for assessing potential and sustainability are needed to Pareto-optimize relations environment. This is important for long-term forecasting, development planning (Batugin, Musina and Golovko, 2017) taking into account doses of key pollutants (Figure 2).

It is necessary to decompose the production and processing system into subsystems. This ensures structural activity and reduced complexity, increased manageability of the system. It is important to have procedures that flexibly take into account the integral connections of subsystems. For the subsystem, as part of the structure, a vector of basic 
REVISTA DE LA UNIVERSIDAD DEL ZULIA. $3^{a}$ época. Año $13 \mathrm{~N}^{\circ}$ 36, 2022

Svetlana E. Germanova et al. /// Environmental security problems in mining areas, 323-338 DOI: http://dx.doi.org/10.46925//rdluz.36.21

factors is specified (without which it is impossible to study the functioning of the subsystem) and the functionality of the subsystem activity.

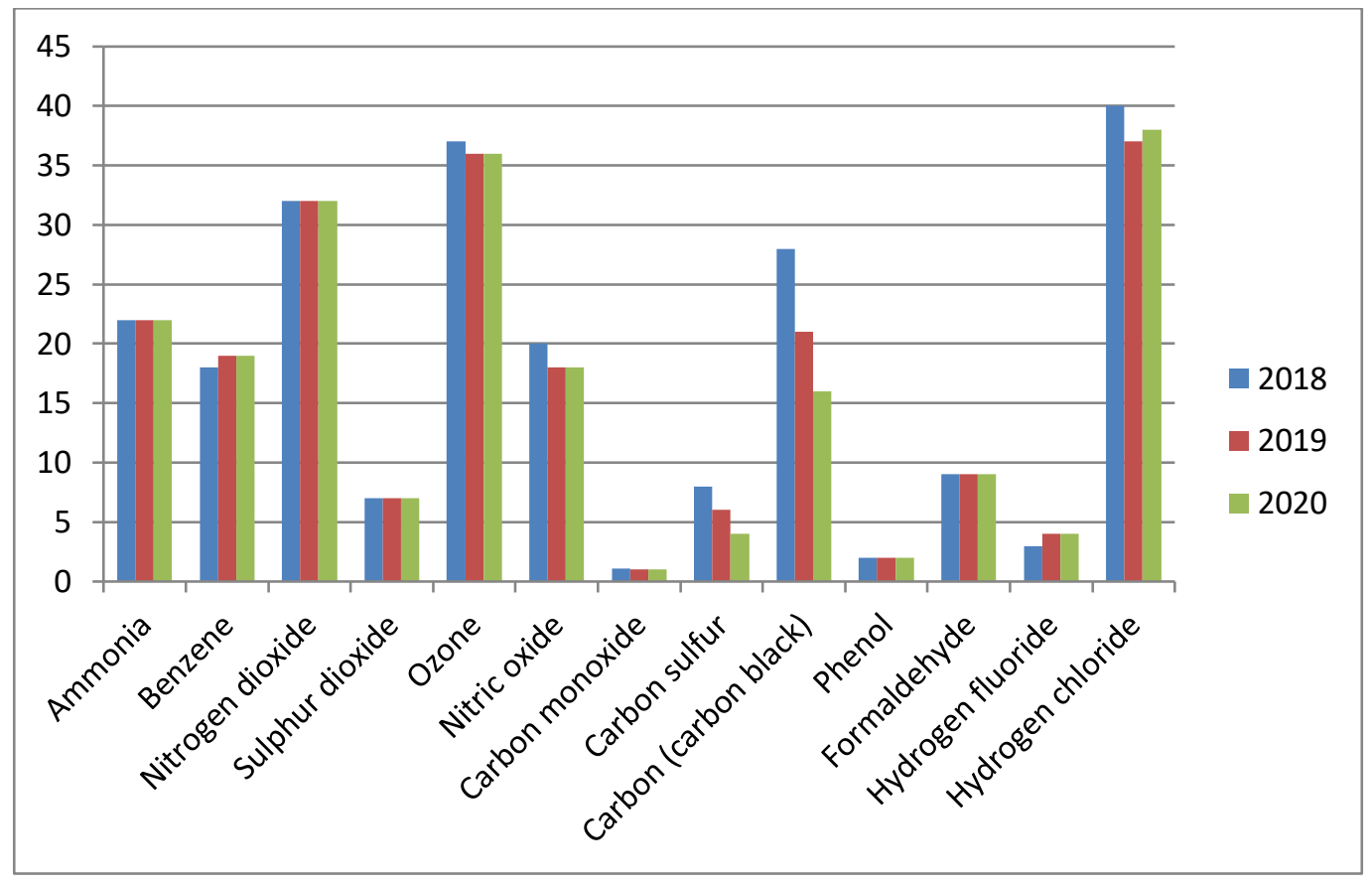

Fig. 2. Concentrations in the Russian Federation, $\mu \mathrm{g} / \mathrm{m}^{3}$

For the whole system, the state vector $x$ and the activity $s(x)$ are identified. In natural systems, speaking of management, we should talk not only about activity, but also about fatigue of the entire system. Fatigue potentials inform the potential for sustainable development.

For example, if the environment resumes system resources, at the rate of view renewal:

$$
\begin{gathered}
\alpha(\tau)=a(\tau)+b(\tau) x(\tau), \\
0<t<T, 0<x<X, 0<\tau<T,
\end{gathered}
$$

then the evolutionary potential of the system can be set by functionality:

$$
\varphi=\int_{0}^{T} \alpha(\tau) e^{-\int_{0}^{\tau} k(s) d s} d \tau,
$$

where $k(s)$ is the natural resource change factor. 
REVISTA DE LA UNIVERSIDAD DEL ZULIA. $3^{a}$ época. Año $13 \mathrm{~N}^{\circ}$ 36, 2022

Svetlana E. Germanova et al. /// Environmental security problems in mining areas, 323-338 DOI: http://dx.doi.org/10.46925//rdluz.36.21

Above the pace - above the potential. And vice versa. No matter how high resources are at the beginning, they are depleted if the potential is less than one.

It is also important to consider that it is necessary to specify a certain set of factors and a set of permissible controls in which there is an achievable optimal (rational according to the selected criterion) value.

The efficiency, sustainability of the mining area depends on the priorities of goals (production, environmental, economic, etc.), the interests of the region, innovation and investment attractiveness.

We offer the following target factors:

1) rational use of land, water and raw materials;

2) recreational opportunities;

3) demographic parameters (fertility, mortality, age-sex structure, etc.);

4) requirements for qualifications, postgraduate education;

5) budgetary financing, increased regional funding;

6) investment opportunities, return on investment;

7) frequency and amplitude of environmental threats, emissions and pollution;

8) dynamism and expansion of production;

9) level of logistics, standardization and unification, production quality;

10) information openness, social activity, unemployment, etc.

An adequate numerical measure is comparable to most criteria. Based on these indicators and their importance (objectivity of accounting), the potential and sustainability of the mining area can be assessed integrally. This is important for the formation of evolutionary functionalities.

In the polluted ecosystem, representatives of both flora and fauna and even technospheres suffer. Everyone experiences an adaptation load in such a system. A systemic sign of restoration of the environment after contamination is, for example, the density and stability of the grass, permissible values of MPC.

These are important criteria for the self-regulation of the ecosystem.

4. Mining areas, geological structures, risks, assessments and their accounting 
REVISTA DE LA UNIVERSIDAD DEL ZULIA. $3^{a}$ época. Año $13 \mathrm{~N}^{\circ}$ 36, 2022

Svetlana E. Germanova et al. /// Environmental security problems in mining areas, 323-338 DOI: http://dx.doi.org/10.46925//rdluz.36.21

The forecast of risk in geological structures, systems is a problem that is relevant in modern geological studies. It is necessary to analyze the instrumental support of systems, communications with the habitat, build appropriate models, identification algorithms and procedures.

In particular, it is necessary to:

1) adaptation techniques, research and development tools;

2) models of accounting and assessment of geological risks in the environment of development and assessment of sustainability of model solutions and forecasting of development and risks;

3) algorithms for modeling and identification, testing, and derivation of causal relationships during work.

The forecast of the business risks, the assessment of possible damage, and the formation of accurate and calculated solutions is a feasible task. Here will help many-agent models (Kaziev, Kazieva, 2019), maximum likelihood criteria (Mazalov, Nikitina, 2018) discrete-event and computer modeling.

Risk - the probability of harm to health, life, environment, next generations and new generations of structures. This is a socio-economic and environmental-economic problem (Trusov, Zaitseva, 2012).

Preventive measures are necessary to adequately counter.

The category "risk-situation" is determined by quantitative indicators of danger, a measure of damage. For example, in absolute (specific), direct (indirect) dimensions.

The infological "portrait" of the environment, the system is determined by the tasks:

1) geoinformational;

2) ecologic-systemic;

3) problem-oriented (concentration of pollutants), etc.

Individual (potential) and regional risks should be considered. Individual risks are assessed by indicators of single pollution (for example, emissions). They are found by experimental dependencies, for example, according to Onishchenko (2002):

$$
R_{i}=1-\exp \left(\ln (0.84)\left(C / P K_{z}\right)^{b} t\right)
$$




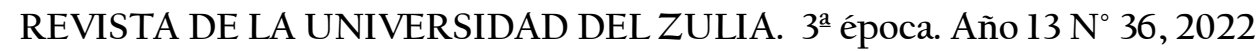

Svetlana E. Germanova et al. /// Environmental security problems in mining areas, 323-338 DOI: http://dx.doi.org/10.46925//rdluz.36.21

where $C$ is the average daily concentration, $P$ is the pollutant MPC; $K_{z}$-medium reserve of "self-cleaning" (7.5, 6.0, 4.5 and 3.0 - respectively, at 1-4 hazard classes); $b$ - coefficient (2.40, $1.31,1.00$ and 0.86$) ; t$ - exposure time, for example, equal to average life expectancy, 76 years (Deryabin and Unguryanu, 2019; Sorokin and Sedykh, et al., 2021).

Individual risk can even be affected by sound pressure during rock explosions (asthenic syndrome, vegetative dysfunctions, etc.). Such risks can be considered integrally by distribution:

$$
R_{z}=\frac{1}{\sqrt{2 \pi}} \int_{-\infty}^{P_{t}} e^{-t^{2} / 2} d t
$$

where

$$
P_{t}=-4.555+0.0853 \mathrm{~L} \text {, }
$$

$L$ is the noise level (decibel).

The population risk of the $i$-th in the order of exposure for the $j$-th factor is found, for example, by the formula:

$$
R_{p}=R_{i j} N,
$$

where $R_{i j}$ is the individual risk, $\mathrm{N}$ is the population of the risk area.

Damage to health in the area can be determined multiplicatively:

$$
Y=\sum_{i=1}^{N} a_{i} \sum_{j=1}^{M} R_{i j} \sum_{k=1}^{K} N_{i j k}
$$

where $a_{i}$ is the cost of damage for the $i$-th single impact, $k$ is the point number on the evolutionary trajectory of the ecosystem.

Especially important are the surroundings of bifurcation points (Muzica, 2011).

You can replace the multiplicative representation with an additive representation to highlight time characteristics (highlight trends by region). In the time series of safety observations (pollutants), seasonal cycles can be distinguished and extrapolated using the maximum likelihood method.

To plan preventive measures, discounted income is found in risk areas: 
REVISTA DE LA UNIVERSIDAD DEL ZULIA. $3^{a}$ época. Año $13 \mathrm{~N}^{\circ}$ 36, 2022

Svetlana E. Germanova et al. /// Environmental security problems in mining areas, 323-338 DOI: http://dx.doi.org/10.46925//rdluz.36.21

$$
N P V=\sum_{i=0}^{N} \frac{P_{i}+\Delta Y_{i}-C_{i}}{(1+r)^{i}}
$$

where $i$ is the serial number of the year, $P_{i}$ is the income for the year, $\Delta Y_{i}$ is the avoided damage, $r$ is the rate of profit, $C_{i}$ is the cost of sale.

Activities with NPV are less costly to consider, although they are important sometimes in social aspects. For the NPV measures selected as they rise, we calculate the IRR, find the measure with the maximum IRR, calculate the net income and form the action plan.

Adaptive manageability and tracking evolutionary functionality change is the path to effective decision-making.

The main thing is to analyze the parameters of the environment, take into account the connections, and flexible selection of the optimal control mode. Relies on adaptive planning, situation testing, and risk states (Figure 3).

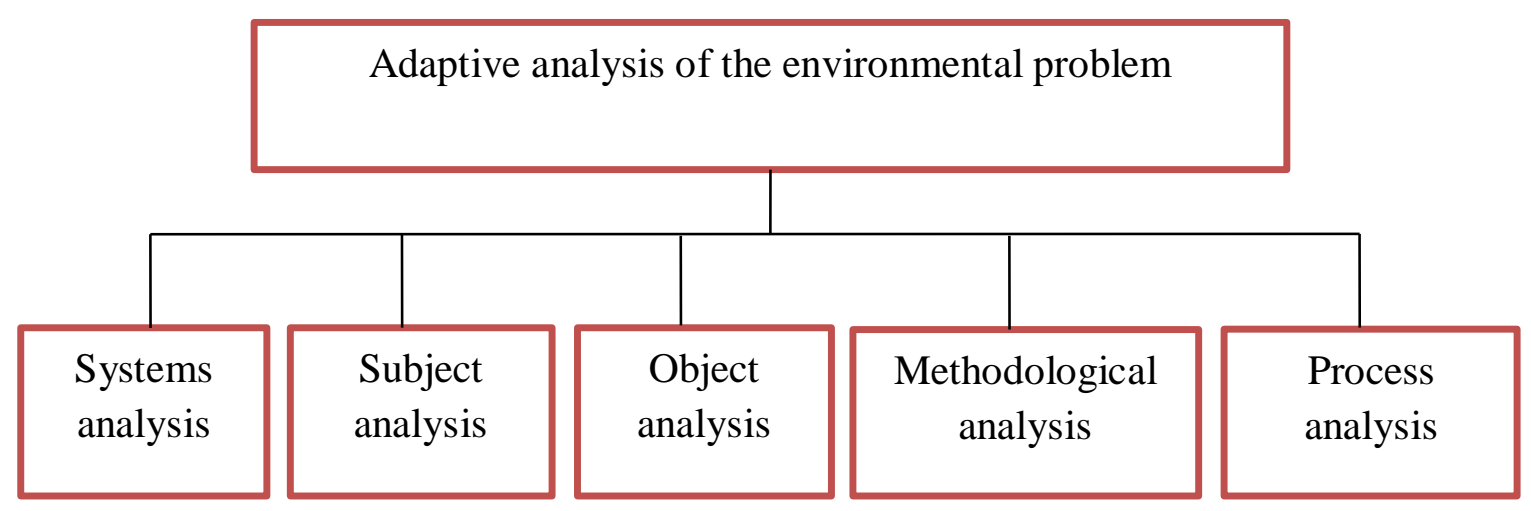

Fig. 3. Levels of adaptive ecosystem analysis

Adaptive modeling allows you to iteratively adjust the strategy (trajectory) of the geoecosystem behavior using control influences and learning the adaptive model in various situations. The study of complex ecosystems is associated with multicriteria, uncertainty in the environment, so manageability and sustainability are the most important and complex problems. 
REVISTA DE LA UNIVERSIDAD DEL ZULIA. $3^{a}$ época. Año $13 \mathrm{~N}^{\circ}$ 36, 2022

Svetlana E. Germanova et al. /// Environmental security problems in mining areas, 323-338 DOI: http://dx.doi.org/10.46925//rdluz.36.21

In the development of adaptive mechanisms, the use of accurate (formalized) models and procedures is difficult. Non-classical approaches are involved, in particular, expertise, heuristics.

Expert and heuristic assessments of mining areas are important for assessments:

1) resource capacity of production;

2) negative impact and self-healing potential;

3) forecast of production volumes, etc.

Such areas are characterized by a variety of types of potential impacts, so system analysis involves expert and heuristic tools, procedures. Dynamic characteristics will need to be analyzed separately and with the effect of their integral effects (Korobov, 2008). But, in our opinion, the methodology of integral estimates is practically absent or they are complex, poorly structured.

Therefore, expert and heuristic assessments in mining areas are given great attention. Researchers, especially practitioners, seek to learn full and relevant analytics about the environment.

Data analytics are the basis of all new technologies that allow you to extract and collect useful information from ore mining data sets and mining areas that would otherwise be impossible to analyze.

The systematic analysis-synthesis will help change the environmental situation for the mining enterprise. Only monitoring of environmental pollution, the availability of relevant measures to improve production safety for the environment is important.

\section{Conclusions}

Applied system analysis is a theoretical basis for modeling (forecasting) not only industrial, but also socio-domestic processes in the ecosystem. Analysis of problems of system safety and geodynamics of mining areas, sustainable process equilibrium is applicable in practical problems, for example, automation of drilling operations, dispatching of production and situational modeling of risk situations.

The evolutionary approach to forecasting the risk situation, adaptability of production to the effects of factors of the mining area provides new practical opportunities. This is facilitated by the application of the results of the system analysis. 
REVISTA DE LA UNIVERSIDAD DEL ZULIA. $3^{a}$ época. Año $13 \mathrm{~N}^{\circ}$ 36, 2022

Svetlana E. Germanova et al. /// Environmental security problems in mining areas, 323-338 DOI: http://dx.doi.org/10.46925//rdluz.36.21

In Industry 4.0, Big Data, Data Mining, and other intelligent decision-making technologies can be used effectively. This will help the proposed approaches to assessing evolutionary potential and risks, the emphasized capabilities of expert and heuristic procedures.

The main information and logical support for predicting the stability of a contaminated environment can be provided by technologies (methodologies): Big Data, Data Mining, classifications, neuro-network, visualization and virtualization, cognitive and geographic information (GIS).

In the management of pollution risks, such integrating and versatile technologies enable rapid decision-making, such as the introduction of full-fledged Smart mining processes into production. Such production, for example, is implemented by the Norilsk Nickel group of companies under the Technological Breakthrough program.

Russian environmental standards are strict, exclude the maximum risks of pollution entering the environment adjacent to the mining enterprise. Reclamation allows the involvement in the economic circulation of land with restrictions on the regimes and conditions of use (in the process of self-restoration). It is in this direction that our results are especially interesting.

As a result of the system studies of processes, it can be concluded that the development of risk situations is influenced by the inherited dynamics from large areas of concentration of mine workings. Such processes also impede the socio-economic development of the territory. It is important to use remote methods to assess situations and developments, degradation of ecosystems and their evolutionary potential. This will help to assess destructive actions, possible damage (environmental debt) and plan appropriate practical measures.

The plan focuses on safety monitoring, long-term interactions, and promising areas of environmental safety.

The variety of criteria and risk assessment methods is a necessary condition of order in the system.

Further development of our research can take various ways. In our opinion, the information-entropy approach is interesting, when the evolutionary potential (functional) is based on the entropy of the system. If the entropy of the current state of the system is large, 
REVISTA DE LA UNIVERSIDAD DEL ZULIA. $3^{a}$ época. Año $13 \mathrm{~N}^{\circ}$ 36, 2022

Svetlana E. Germanova et al. /// Environmental security problems in mining areas, 323-338 DOI: http://dx.doi.org/10.46925//rdluz.36.21

the pollution process is underway. If it is so large, then the given system may not become cleanable at all.

Our approach and procedures are technological, simple and flexible. They do not involve complex monitoring studies, they allow you to enter the regimes of self-organization and self-purification of vegetation cover and land subsoil.

\section{References}

Batugin A.S. (2020) A proposed classification of the earth's crustal areas by the level of geodynamic threat, Geodesy and Geodynamics, 12(4). DOI: 10.1016/j.geog.2020.10.002

Batugin A.S., Musina V.R., Golovko I.V. (2017), Analysis of Geodynamical Conditions of Region of Burning Coal Dumps Location, IOP Conference Series: Earth and Environmental Science, 95, 29:37.

Brusseau M., Pepper I., Gerba Ch. (2019) Environmental and Pollution Science. 3rd Edition. Academic Press. 662 p. ISBN: 9780128147191

Deryabin A.N., Unguryanu T.N., Buzinov R.V. (2019) Public health risk associated with exposure to soil chemicals, Health risk analysis, 3, 18:25. DOI: 10.21668/health.risk/2019.3.02.

Gayev A.Ya., Kilin Yu.A. (2018) About ensuring of ecological safety in mine extractive regions on the base of negative karst processes minimization. RUDN Journal of Ecology and Life Safety, 26(1), 35-51. DOI 10.22363/2313-2310-2018-26-1-35-51

Kaziev V.M., Kazieva B.V., et al. (2019) Modeling multi-agent interactions in network economics. Collection: "Modern problems of applied mathematics, computer science and mechanics." - Nalchik: KBSU, 22-27.

Kaledina N.O., Kobylkin S.S., Kobylkin A.S. (2016) The calculation method to ensure safe parameters of ventilation conditions of goaf in coal mines, Eurasian Mining, 1(25), 41:44.

Kobylkin A., Musina V., Batugin A. et al. (2019) Modelling of Aerodynamic Process for Coal Waste Dump Located in Geodynamically Dangerous Zone. IOP Conference Series: Earth and Environmental Science, 221 (1), 012087. DOI: 10.1088/1755-1315/221/1/012087

Kolesnikova L.A., Kovalchuk T.V. (2021) Problems and prospects for the environmental safety of mining regions. Mining Information and Analytical Bulletin, 2(1), 275-286. DOI: $10.25018 / 0236-1493-2021-21-0-275-286$

Korobov V.B. (2008) Expert methods in geography and geoecology. Arkhangelsk, 236 p.

Kulikova E.Yu., Balovtsev S.V. (2020) Risk control system for the construction of urban underground structures. IOP Conference Series: Materials Science and Engineering, 962 042020. https://doi.org/10.1088/1757-899X/962/4/042020. 
REVISTA DE LA UNIVERSIDAD DEL ZULIA. $3^{a}$ época. Año $13 \mathrm{~N}^{\circ}$ 36, 2022

Svetlana E. Germanova et al. /// Environmental security problems in mining areas, 323-338

DOI: http://dx.doi.org/10.46925//rdluz.36.21

Liang Y., Xiao H., Liu X., Shi H. (2020) The risk and phytotoxicity of metal(loid)s in the sediment, floodplain soil, and hygrophilous grasses along Le'an River, International Journal of Environmental Science and Technology, 17, 1963-1974. DOI: 10.1007/s13762-019-02592-0.

Mazalov V.V., Nikitina N.N. (2018) Method of maximum likelihood for highlighting communities in communication networks, Bulletin of St. Petersburg State University (ser. "Applied mathematics. Computer science. Control Processes"), 14(3), 200:214. https://doi.org/10.21638/11702/spbul0.2018.30

Muzica O.A. (2011) Bifurcation in nature and society: natural-scientific and socio-synergistic aspect, Modern knowledge-intensive technologies, 1, 87:91. URL http:/www.toptechnologies.ru/ru/article/view?id=26640 (case date: 20.02.2020).

Onishchenko G.G. (2002) Public Health Risk Assessment Framework for Environmental Chemicals: Moscow, NIIIEH, 408 p.

Sklarew D., Sklarew J. (2018) Integrated Water-Energy Policy for Sustainable Development // Foresight and STI Governance, 12(4), 10-19. DOI: 10.17323/2500-2597.2018.4.10.19.

Shafiquzzaman M., Alharbi S., Haider H. et al. (2020) Development and evaluation of treatment options for recycling ablution greywater, International Journal of Environmental Science and Technology, 17, 1225-1238. DOI: 10.1007/s13762-019-02537-7.

State report (2019). On the state and protection of the environment of the Russian Federation in 2018. Moscow: Ministry of Natural Resources of the Russian Federation.Cadastre, 844 p. https://www.mnr.gov.ru/docs/gosudarstvennye_doklady/proekt_gosudarstvennogo_doklad a_o_sostoyanii_i_ob_okhrane_okruzhayushchey_sredy_rossiyskoy_federat2019/ (approved data: 24.11.2021)

Statistical Review of World Energy (202l). https:/www.bp.com/content/dam/bp/businesssites/en/global/corporate/pdfs/energy-economics/statistical-review/bp-stats-review-2021full-report.pdf (approved data: 24.11.2021).

Skopintseva O.V., Balovtsev S.V. (2021) Air quality control in coal mines based on gas monitoring statistics. MIAB. Mining Inf. Anal. Bull, 1(1):78-89. DOI: 10.25018/0236-14932021-1-0-78-89.

Sorokin A.E., Sedykh V.A., Savich V.I. et al. (2021) Information Assessment of Soil-Plant Interactions, International Agricultural Journal, 1 (379), 17:21. DOI: 10.24412/2587-67402021-1-17-21

Tarazanov I.G., Gubanov D.A. (2020) Results of the coal industry of Russia for January, December 2020, Coal, 3, 54-69. DOI:10.18796/0041-5790-2020-3-54-69.

Trusov P.V., Zaitseva N.V., Kiryanov D.Ya. et al. (2012) Mathematical model of the evolution of functional disorders in the human body taking into account external environmental factors, Mathematical biology and bioinformatics, 2, 589:610. 